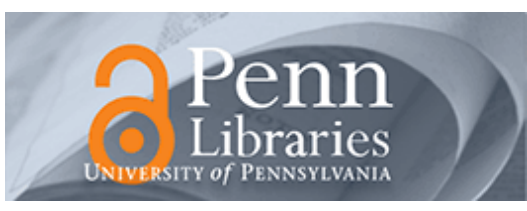

University of Pennsylvania ScholarlyCommons

Departmental Papers (Sociology)

Penn Sociology

1978

\title{
The Timing of Marriage in the Transition to Adulthood: Continuity and Change, 1860-1975
}

John Modell

Frank F. Furstenberg

University of Pennsylvania, fff@ssc.upenn.edu

Douglas Strong

Follow this and additional works at: http://repository.upenn.edu/sociology_papers

Part of the Family, Life Course, and Society Commons

\section{Recommended Citation}

Modell, John, Frank Furstenberg, and Douglas Strong. 1978. "The Timing of Marriage in the Transition to Adulthood: Continuity and Change, 1860-1975." American Journal of Sociology 84 (Supplement: Turning Points: Historical and Sociological Essays on the Family): S120-S150.

This paper is posted at ScholarlyCommons. http://repository.upenn.edu/sociology_papers/11

For more information, please contact repository@pobox.upenn.edu. 


\section{The Timing of Marriage in the Transition to Adulthood: Continuity and Change, 1860-1975}

\section{Disciplines}

Family, Life Course, and Society | Sociology 


\title{
The Timing of Marriage in the Transition to Adulthood: Continuity and Change, 1860-1975'
}

\author{
John Modell \\ University of Minnesota and Philadelphia Social History Project \\ Frank F. Furstenberg, Jr., and Douglas Strong \\ University of Pennsylvania
}

\section{INTRODUCTION}

All societies are age graded to a degree and must, therefore, make some provision for marking and sanctioning the orderly passage from one stage of life to the next. The patterning of social transitions provides an unusually good site from which to observe regularities of a social system over time. Clearly, the ways in which such transitions are accomplished are not fixed features of any given society but are subject to renegotiation as social and economic conditions change. In turn, the alteration of social schedules may itself be a source of change, bringing about shifts in other social institutions. Such alterations, though sometimes subtle, are a prime subject for inquiry.

Remarkably little attention in the literature on family history has been given to the subject of transitions. Most family scholars, attempting to depict change over time, have fixed their interest on shifts in household size, composition, and headship (Hareven 1976). In this excessive preoccupation with the organization of the household, more dynamic processes have been slighted; it is almost as though it were necessary to make the family stand still in order to appreciate that it has changed.

Both on an aggregate and an individual level, it is easy to treat events

1 The present essay develops ideas first explored by the senior authors (with Theodore Hershberg) in "Social Change and Life Course Development in Historical Perspective" (1976). In turn, the latter piece was in good measure a response to questions raised by work on the life course by Elder, esp. in his Children of the Great Depression (1974). Furstenberg (1975) and Modell (1975) have each published review essays of the Elder book. Elder (with Richard Rockwell) also addressed the question of marital age in a paper delivered at the 1975 annual meetings of the ASA. Research for the present essay was carried out at the Philadelphia Social History Project, University of Pennsylvania, with the financial support of the Center for the Study of Metropolitan Problems, National Institute of Mental Health (grant MH 16621). We thank Theodore Hershberg, director of the Philadelphia Social History Project, for his colleagueship and scholarly involvement during the writing of this paper. We wish also to thank, for thoughtful readings, George Alter, Saundra-Lynn Coulter, Glen Elder, Jr., Sara Evans, Claudia Golden, William Wilcher, our colleagues at the Russell Sage-AJS conference, and two anonymous readers for the Journal.

(c) 1978 by The University of Chicago. 0002-9602/79/8407-0004\$02.63

S120 AJS Volume 84 Supplement 
such as marriage, birth, death, or any important status transition as if they occurred in isolation. Status transitions only take on meaning, however, when they are placed in a social context, as significant moments in "the persistent organic interdependency of the cohort-specific life history" (Ryder 1965, p. 290). The approach we adopt begins by observing regularities in the timing of human events, and ultimately seeks to account for the sequencing of these events in the life span. ${ }^{2}$ Thus, for example, to make sense of conjugal timing-as we shall try to do in this paper-we must examine the distribution of conjugal careers of age peers. Earliness or lateness of marriage are terms that acquire meaning only when individuals are examined in the context of a particular cohort, or when one cohort is seen in the light of the experience of other cohorts.

There is another sense in which the examination of conjugal timing must be viewed in a social context. The timing of marriage can best be understood when it is related to other status transitions which typically follow or closely precede the entrance to matrimony. A shift in marriage age is a relatively trivial finding unless this change is seen in the context of the timing of other events in the familial career such as entrance to the labor force, establishment of a household, or first birth. Rather than looking at marriage age as a separate demographic or psychological phenomenon, we view it as one feature in the allocation of roles to members of a cohort and in the construction of the life course of the constituents of this cohort (Riley, Johnson, and Foner 1972).

Placing the question of marital timing in a life-course perspective is easier to do in theory than in practice. The historical data, and even the contemporary data on nuptial age, do not readily fit the type of analysis we are advocating. We are on fairly firm ground in our analyses of the distribution or variation of marriage age over time, but when we take up the relationship of marriage to other life events the data do not always carry us as far as we might like. Our ideal end-to establish changes in the social construction of familial "careers" among the members of successive cohortscan only be approached by stretching the historical data to (and perhaps in some instances beyond) its limits. Experience is longitudinal, but both population lists and event lists are rarely in longitudinal form. Our contrived life-course analysis suggests where true longitudinal work might profitably begin, for the meaning of "timing" is visible only when conceived as part of a career and these careers as characteristic experiences of cohorts.

This temporal or life-course perspective, we believe, offers distinct advantages to social historians. First, by observing how individuals re-

2 We detect a similar strain emerging as well in the area of stratification studies. Haller and Portes (1973, pp. 53 and 55), e.g., note that research in this field has turned from singleattribute "mobility scores" to the study of "the process of stratification" and that therefore "a theory of status attainment ... must ... take into account possible changes occurring in the structure of status systems." 
sponded to particular constraints and options at critical junctures in their life courses, we have some basis for assessing their preferences and predilections. In so doing, we may gain some sense of how individuals actively responded to changing opportunities. Second, shifts in the construction of the life course themselves become an impetus for institutional change. As alterations occur in the sequence or timing of life events, other features of society must often be modified accordingly. The timing of marriage, to cite the example we shall explore in this paper, is not merely a reflection of institutional change but a source of change, instigating economic and social innovations (e.g., the provision of married-student housing by universities).

Our principal objective in this paper is to illustrate the value of examining historical data from this perspective. Our analysis follows a stepwise procedure, building out from simple constructs (the transition to marriage) to more complex ones (family formation). Substantively, we shall attempt to show that a significant transformation has taken place in the process of family formation over the past century. The data with which we establish these trends will not permit us to explain with any degree of precision why changes occurred when they did, but the coincidence of events will suggest some possible interpretations.

Our analysis divides into two parts. The first, a descriptive section depicting nuptial trends over the past century, will present data not new to scholars in the field, although sometimes we have organized this material in novel ways. In the second part of the paper, we will show how the changes in nuptial timing which occurred in this century reoriented the whole process of family formation. This discussion will lead us to some plausible ways of interpreting the emergence of the more contemporary pattern of family formation, interpretations we hazard at the conclusion of our essay.

\section{Patterns of Marriage Timing}

Though marriage age has long been a topic of speculation in the literature of family sociologists, few scholars took the trouble to assemble quantitative materials from earlier times before Monahan's pioneering though somewhat chaotic study of the subject in 1951. Monahan took previous observers to task for their tendency to treat marriage age as a simple function of industrialization and urbanization. Drawing upon the existing data at the time which could be extracted from federal, state, and local censuses, and from state and local vital registration systems, he came to the conclusion that age at marriage in the early United States was essentially the same as in 1890, when U.S. census data on marital status began to permit closer scrutiny. ${ }^{3}$ Glick (1957) and his collaborators (Carter and Glick 1970) and,

${ }^{3}$ The evidence that Monahan uses is quite varied and subject to a variety of biases. We have subjected one of the more substantial sets of these data to a more refined analysis than Monahan was able to perform. A close examination of the Michigan and New York 
independently, Jacobson (1959) have generally buttressed Monahan's interpretation of the historical record. The work of these scholars indicates that neither rapid nor sustained long-term changes in median age at marriage occurred until the 1940s.

Table 1 abstracts the marriage experience of U.S. birth cohorts dating to the mid-19th century, drawing from successive census reports. Table 2 presents similar information from single-year periods of first marriages in Massachusetts over roughly the same period. The cohort reports (if we

TABLE 1

MEdian, First AND NinTh DEcILES, SPREAd OF FirST MARRIAGE, AND ESTIMATED PROPORTION EVER MARRIED FOR COHORTS BORN 1865-1874 TO 1925-1934, UNITED STATES

\begin{tabular}{cccccc}
\hline \hline Birth Cohort & $\begin{array}{c}\text { Midpoint for } \\
\text { Those Who } \\
\text { Married }\end{array}$ & $\begin{array}{c}\text { First } \\
\text { Decile }\end{array}$ & $\begin{array}{c}\text { Ninth } \\
\text { Decile }\end{array}$ & Spread & $\begin{array}{c}\text { Proportion } \\
\text { Ever } \\
\text { Married }\end{array}$ \\
\hline & & & Males & & \\
\hline $1865-1874 \ldots \ldots \ldots$ & 26.2 & 19.7 & 38.6 & 18.9 & 90.2 \\
$1875-1884 \ldots \ldots$ & 25.9 & 19.4 & 38.9 & 19.5 & 91.6 \\
$1885-1894 \ldots \ldots$ & 25.5 & 19.1 & 38.0 & 18.9 & 92.3 \\
$1895-1904 \ldots \ldots$ & 25.0 & 18.8 & 37.1 & 18.3 & 92.5 \\
$1905-1914 \ldots \ldots$ & 25.1 & 18.9 & 38.2 & 19.3 & 93.9 \\
$1915-1924^{*} \ldots \ldots$ & 24.2 & 19.0 & 31.8 & 12.8 & 94.7 \\
$1925-1934^{*} \ldots \ldots$ & 23.4 & 18.3 & 31.0 & 12.7 & 94.9 \\
& & & Females & & \\
$1865-1874 \ldots \ldots$ & 23.8 & 19.0 & 31.9 & 12.9 & 91.1 \\
$1875-1884 \ldots \ldots$ & 23.6 & 18.9 & 31.9 & 13.0 & 91.1 \\
$1885-1894 \ldots \ldots$ & 22.9 & 18.8 & 30.4 & 11.6 & 92.1 \\
$1895-1904 \ldots \ldots$ & 22.6 & 18.7 & 30.3 & 11.6 & 92.2 \\
$1905-1914 \ldots \ldots$ & 22.4 & 18.7 & 31.6 & 12.9 & 93.1 \\
$1915-1924^{*} \ldots \ldots$ & 22.5 & 18.8 & 27.3 & 8.5 & 94.6 \\
$1925-1934^{*} \ldots \ldots$ & 21.0 & 18.3 & 26.6 & 8.3 & 94.9 \\
\hline
\end{tabular}

Sources.-Marital status by sex and age data from U.S. Bureau of the Census (1913, 1922, 1933a, 1943b, $1953 a, 1964 a, 1972$ ).

* Includes extrapolations into future.

state censuses for 1854-55 and 1874-75 strongly indicates that the urban/rural and east/ west variations in age at marriage (derived from proportions married in age-standardized populations) existed in the 1850 s as in the $1870 \mathrm{~s}$ and, as can be systematically observed, in the 1890 federal census. But there are no trends whatever in these years, except what is owing to an occasional tendency in Michigan toward more even sex distributions and thus more effective marriage markets. The period of early industrialization, thus, saw none of the shift in marriage patterns that had been inferred from literary sources. There are suggestions-again confirming Monahan-that this finding of basic stability can be pushed back even further to 1825 , based on the analysis of age-standardized proportions of women married in three decennial New York state censuses, 1825 through 1845 (see References for details of census sources). We do not preclude the possibility of cyclical variations during the 19th century similar to those described by Katz elsewhere in this volume, but the available data seem to show no secular trend during the early phase of industrialization in the United States. 
assume a closed population) may be viewed as a rough proxy for longitudinal data. The period data on marriages, on the other hand, depict all the first-marriage events taking place in a single year. As such, they are subject to considerable variation from year to year as the population of marriers changes in size and composition. ${ }^{4}$ Despite the very different basis of the two

TABLE 2

Median, First and Ninth Deciles, ANd SPREAD of FIRST MARRIAGE, SELECTED YEARS

1867-1971, MASSACHUSETTS

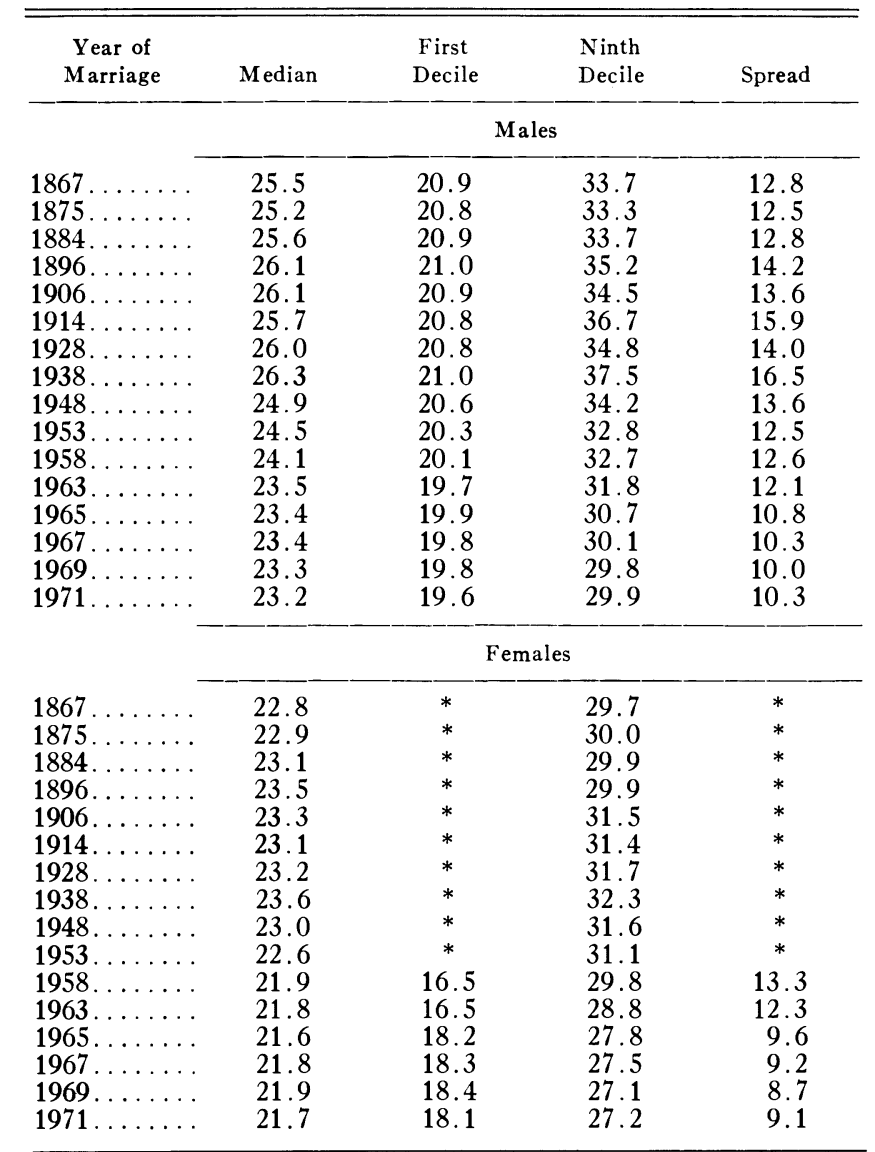

\footnotetext{
Sources.-First marriages by age from Massachusetts, Vital Statistics (various years).

* Cannot be calculated since 10th percentile falls in lowest tabulated age group.
}

The reader should be aware that an effective national marriage registration system was not created in this country until the 1950s and even then published less rich data than did some of the states and localities. Massachusetts developed the first adequate state registration system, for all vital events, in the United States and was one of the few states to 
tables, the gross cohort patterns evidently outweigh annual variation, and the two tables yield approximately the same picture-a remarkable stability in age at marriage during all but the most recent part of the past century. The post-World War II drop in marriage age reveals a magnitude of change which the slow and measured decline prior to 1920 in no way approaches.

Finer calculations probably would show some amount of fluctuation of the median, but the overall pattern of long-term stability is hard to dismiss. This pattern is especially noteworthy in view of the enormous social and economic transformation that occurred in the late-19th and early-20th centuries. Massive immigration, westward population movement, and both urban and industrial growth left surprisingly little trace on the age at marriage of both males and females during this period. Rather than long-term developments in the economy or composition of the population gradually bringing age of marriage down, it was the widely publicized marriage boom of the 1940s that did so, at an unprecedented rate.

Not only did the period after World War II mark an abrupt decline in marriage age, but it signified another important departure in the timing of marriage. Although in theory the ages at which members of a birth cohort marry could scatter in an infinite number of ways, in fact the distribution assumes a probabilistic form. The shape of this marriage curve is determined by at least two independent parameters, namely, the initial age at which transition to marriage commences for the cohort and the proportion of those who ever wed (Coale 1971; Hernes 1972). ${ }^{5}$

When one examines marriage spread-the amount of time it takes a cohort to achieve its maximal proportion ever married-it is clear that an important change has taken place since the 19th century. ${ }^{6}$ Eliminating the

provide first-marriage data for the 19th century. For these reasons, we, like others using state statistical materials for historical inquiry, rely heavily upon Massachusetts even while recognizing its atypicality in degree of industrialization and in some demographic features. Period data which are weaker both conceptually and in coverage are introduced for a very particular reason. We wish to show that the changes in marriage patterns which we describe were neither peculiar to a single region nor merely a function of a complicated population redistribution. We also wish to establish that the timing of the changes is so striking that the points of inflection can be seen in records of marriage events as well as in the marital statuses of individuals. We are looking for trends, not exact measures of levels; and the two data sources ought on the whole to agree, their testimonies to reinforce one another. In the case of age at marriage, the Massachusetts data are also supported by various data from New York, New Jersey, Rhode Island, and Michigan, all cited by Monahan, and by materials from Philadelphia which we were able to examine in considerable detail.

'Coale (1971) assumes the independent "setting" of minimum marriage age, and age for completion of the marriage process, for a given cohort. Hernes's (1972) alternative model for the nuptial process would express our observation as an increase in the initial marriageability, offset by an increase in the deterioration of marriageability with age.

${ }^{6}$ The measure is described more fully elsewhere (Modell et al. 1976). In essence, we are applying techniques of interpolation from grouped data, that might be used for computing 
two extreme tails - the youngest $10 \%$ to marry and the oldest -in the 19th century, it took 15 or more years for $80 \%$ of the men who ever wed to marry and roughly 12 or 13 years for the same proportion of women to enter wedlock. Recent data show that there is now much less variation in the age at marriage. The central $80 \%$ of the 1925-34 birth cohort of male evermarriers managed the transition in 8.6 years, and the females did so even more rapidly. Table 3 shows the proportion of all marriages which are achieved in the top three modal years of age for the marriage of successive cohorts. These figures provide further corroboration for the conclusion that modality in marriage timing has markedly increased for both men and women, though the changes among the males are again more dramatic (Ryder 1969).

The data presented in tables 1, 2, and 3 not only establish that modality has increased over time but they also help to pinpoint when this change took place. Marriage age did not become more narrowly bounded until after the Second World War, despite the gradual lowering of the median age before 1920. But there was a sharp reduction in the spread of marriage for both sexes in the late 1940s. This trend, of course, corresponded to the conspicuous drop in marriage age which we noted earlier. Up to that point, there had been a remarkable degree of constancy in marriage spread during the previous half century. Although it is difficult to bring the figures up to the recent

TABLE 3

Proportion of all Marriages Contracted through Age 34 Attributable To Three Most Marriage-Prone Years of Age For Single-Year BIRTH COHORTS 1885-1935, UNITED STATES

\begin{tabular}{|c|c|c|c|c|}
\hline \multirow{2}{*}{$\begin{array}{c}\text { YEAR of } \\
\text { BIRTH }\end{array}$} & \multicolumn{2}{|c|}{$\begin{array}{l}\text { \% Marriages-through Age } 34, \\
\text { Encompassed in Three Top Years }\end{array}$} & \multicolumn{2}{|c|}{ Top Three Years of Marriage } \\
\hline & Male & Female & Male & Female \\
\hline 1885 . & 24.1 & 28.4 & $22,24,25$ & $19,20,21$ \\
\hline 1890 . & 27.3 & 27.6 & $22,23,24$ & $19,20,21$ \\
\hline 1895. & 28.2 & 27.4 & $22,23,25$ & $18,19,20$ \\
\hline 1900 . & 27.6 & 30.9 & $21,22,23$ & $19,20,21$ \\
\hline 1905 . & 28.1 & 30.3 & $22,23,24$ & $18,19,20$ \\
\hline 1910. & 25.7 & 29.1 & $23,24,25$ & $18,19,20$ \\
\hline 1915 . & 28.5 & 28.9 & $22,23,25$ & $19,20,21$ \\
\hline 1920 . & 21.6 & 32.5 & $21,22,23$ & $20,21,22$ \\
\hline 1925. & 38.4 & 34.2 & $21,22,23$ & $18,21,22$ \\
\hline 1930. & 33.7 & 37.6 & $20,21,22$ & $18,19,20$ \\
\hline $1935 \ldots \ldots$ & 35.7 & 38.8 & $20,21,22$ & $18,19,20$ \\
\hline
\end{tabular}

SOURCES.-Retrospective data on age at first marriage by sex and single year of age from U.S. Bureau of the Census $(1966,1973 b)$.

a median, to compute the point of the first and ninth deciles. The number "ever married" is taken to be the highest proportion ever married listed for any age group. Glick (1957; and Carter and Glick 1970) has on several occasions used the interquartile range of age at marriage as a spread measure but has made little of it. 
present because more recent cohorts have not yet completed their marriage transition, there is no reason to believe that the change after World War II was short-lived. Both recent registration figures from Massachusetts and estimates of nuptial timing based on Current Population Surveys suggest that the high degree of modality continues, slightly modified, even though marriage age has started to climb. Apparently, the marriage spread for females has increased somewhat during the past decade (though it is still far below its prewar level). For males, marriage spread has remained quite stable (U.S. Bureau of the Census 1975).

When we look more closely at the figures presented in table 2, the components of the trend toward modality are immediately apparent. After the war, little change occurred in the age at which the first tenth of the age cohort married, but a vast amount of change took place in the behavior of the later deciles. Generally, the "late" marriers entered matrimony much earlier than had been the case in previous eras. Except for a few stragglers, the market virtually closed down for women after their midtwenties, and for men by their late twenties. There was a rapid disappearance of eligible bachelors in their thirties, and spinsterhood, the point when women are at an age disadvantage in the marriage market, appears to have come earlier in recent times. The distribution by age and sex of the single and the currently married populations shows dramatically the virtual disappearance of a once-significant part of the population-the single adult. At the same time, the age structure of the married population has shown remarkable stability, owing to the offsetting effects of marriage age and mortality.

Initially, the "marriage rush" which began in the early 1940s affected single people of all ages in much the same way. Marriage probabilities for very young men and women increased especially markedly in the early postwar period as compared with 1940. But even for those who did not marry young, the probabilities of marriage at a later age increased. ${ }^{7}$ The first phase of the marriage rush, then, reduced the spread partly by giving a special boost to young marriers and partly by simply increasing the proportion marrying at all ages including the young. This had the effect, in view of their already relatively high marriage probabilities, of removing eligibles from the marriage market at an earlier point in the life span. At the same time, however, there was no backing away from marriage by the depleted single remnants of the older cohorts.

By the end of the 1950s, a new pattern emerged: while the annual probabilities of marriage for both sexes were still rising, the marriage market

${ }^{7}$ These statements are based on the probability-of-marriage tables (with decrement for death) for 1940 and 1948 compiled by Jacobson (1959). The 1940 table shows a general increase in marriage probabilities over Grabill's (1945) table representing the experience of the 1920s and 1930s rather than a shift in the age schedule of probabilities. 


\section{Modell, Furstenberg, and Strong}

soured for older singles-men and women in their mid-twenties and oldereven though proportions remaining single throughout the reproductive span declined. ${ }^{8}$ The postwar pattern of more modal marriage, initially a function largely of generally heightened probabilities of marriage, was now reinforced by a new age-specific marriage schedule. Older marriage probabilities became somewhat depressed, absolutely, even as younger singles increased their marriage probabilities. Viewed from a life-course perspective, marriage is always something of a segregation process: those who by a particular age fail to marry find their subsequent chances of ever marrying narrowing each year. Between the postwar rush and the end of the 1950s, this selective process became even more pronounced.

Along with the greater degree of uniformity in the marriage timing of individuals came a greater degree of coordination of marriage age between couples. This more or less follows from what we have seen above. As the spread narrowed for both men and women, it might be expected that age difference among couples would drop. Unfortunately, extensive historical data on single-year age-at-marriage differences among couples do not exist. Some fragmentary data reported by Monahan do support the assumption that age homophily in marriage rose in the 20th century. Massachusetts data, presented in table 4, show some movement in the average relationship

TABLE 4

Means and Standard Deviations of the Ages of BRIDES OF FIRST-TIME GROOMS MARRYING AT AGES 20-24 AND 25-29, MASSACHUSETTS, 1871-1963

\begin{tabular}{|c|c|c|c|c|}
\hline & \multicolumn{4}{|c|}{ AGE of GroOM } \\
\hline & \multicolumn{2}{|c|}{$20-24$} & \multicolumn{2}{|c|}{$25-29$} \\
\hline & $\begin{array}{c}\text { Mean Bride } \\
\text { Age }\end{array}$ & SD & $\begin{array}{c}\text { Mean Bride } \\
\text { Age }\end{array}$ & SD \\
\hline $\begin{array}{l}1871 \ldots \ldots \\
1882 \ldots \ldots \\
1892 \ldots \ldots \\
1902 \ldots \ldots \\
1913 \ldots \ldots \\
1927 \ldots \ldots \\
1938 \ldots \ldots \\
1948 \ldots \ldots \\
1953 \ldots \ldots \\
1958 \ldots \ldots \\
1963 \ldots \ldots\end{array}$ & $\begin{array}{l}20.0 \\
20.2 \\
20.3 \\
20.3 \\
20.3 \\
20.1 \\
20.3 \\
20.1 \\
20.0 \\
19.7 \\
19.7\end{array}$ & $\begin{array}{l}2.06 \\
2.19 \\
2.21 \\
2.26 \\
2.26 \\
2.21 \\
2.26 \\
2.05 \\
1.98 \\
1.81 \\
1.58\end{array}$ & $\begin{array}{l}21.9 \\
22.1 \\
22.3 \\
22.6 \\
22.2 \\
22.3 \\
22.6 \\
23.3 \\
23.2 \\
22.9 \\
22.6\end{array}$ & $\begin{array}{l}3.12 \\
3.11 \\
3.20 \\
3.40 \\
3.38 \\
3.34 \\
3.34 \\
3.30 \\
3.38 \\
3.33 \\
2.98\end{array}$ \\
\hline
\end{tabular}

Sources.-Same as table 2.

${ }^{8}$ Cf. Jacobson's 1948 table to the one for $1958-60$ constructed by Saveland and Glick (1969). Differences in compiling procedure do not affect our generalizations. Retrospective sample data, from a later survey of economic opportunity, which are somewhat unreliable, seem to suggest that in the early 1960 s there was a collapsing toward modality at both the young and old ends of the marriage period (U.S. Bureau of the Census 1970). 
between the groom's age at first marriage and that of the bride. But the clearest trend is once again seen after World War II, when grooms in the modal age category (20-24) seemingly selected younger brides and with declining frequency chose brides in older age categories, upsetting what had been a rather stable 19th-century pattern. At this point, too, began a steady decline in the standard deviation of the ages of brides who married this modal set of grooms. The process to matrimony now linked mates more nearly similar in age, and did so more uniformly. The increasingly narrow range of brides' ages was, one suspects, a reflection of the changing social settings in which mates were being discovered (school being the most obvious of these). ${ }^{9}$ At the same time as a shift was taking place in the site of the marriage market, the market itself was becoming more homogeneously age graded.

Thus far, we have located several important dimensions of nuptial timing and have observed their change over time. Most of the remainder of the essay will be devoted to investigating the marriage transition in the context of other alterations that were taking place in the whole sequence of family formation. Examining the more complex sequence of family formation will help to elucidate the social meaning of changes we have already observed and may offer certain insights into how and why changes in the nuptial patterns came about.

\section{Structural Contexts of Marriage}

The argument that will unfold in the following sections is briefly that there has been a relaxation of constraints upon the ability to marry that allowed the timing of marriage to become increasingly preferential. People have become relatively more free to marry according to preference because structural conditions impose fewer obstacles to matrimony than was once the case. What we have termed "structural" conditions range from the largely extrafamilial and impersonal forces of a marriage market to the very private and personal decisions such as the practice of birth control.

Under the rubric of "structural" conditions we include, too, changes in the economic situation of young adults. There is no question that the extraordinary productivity of the United States is connected in some way to its marriage patterns, which by comparison to countries in Western Europe have always been highly youthful. But the commonsense idea that nuptial timing responded directly to an increasingly productive economy is mistaken. The historical record belies any simple translation of gains in productivity

${ }^{9}$ Rockwell's examination (1976) of educational homogamy indicates that for nonwhites the strongest tendency away from "random mating" (with respect to educational attainment) occurred shortly after World War II, but that for whites it was a prewar product, after which it declined slightly, before eventually stabilizing. This trend is over and above whatever increased age grading was occurring in educational institutions. 
into more youthful or uniform marriage. Thus, productivity gains in the late-19th century, and the bursts of rapid improvement in disposable income per capita (Long 1960; U.S. Bureau of Economic Analysis 1973), scarcely budged marriage timing. At the beginning of the 20th century, age at marriage declined during two decades of considerable economic growth and then leveled off. But these trends correspond poorly to the inflexible patterns of marriage modality. The war quinquennium was, of course, one of spectacular economic advancement; but it was followed by five years of real decline in disposable income. Only after 1950 or so did the improvement in disposable incomes per capita again increase. Our contemporary timing patterns were established during a period of relative stagnation in the immediate postwar period but have declined relatively little during two decades of rapidly expanding personal resources.

\section{The Marriage Market}

Material conditions are not the only structural constraints to contracting marriage at the moment one chooses. One needs to find a suitable mate, and opportunities for courtship vary according to social setting. A way of visualizing these settings is as a marriage market. The demographic characteristics of the participants in the market, the cultural rules prescribing the range of suitable matches, and the geographical extensiveness of the market pool together affect patterns of nuptiality. Many individuals, when marriage markets were not very orderly, may have married late because they were unable to find expeditiously a mate they considered suitable (Groves and Ogburn [1928] provide an early empirical examination of marriage markets in the United States). We will only adumbrate here the complex process by which marriage markets became more efficient, confining ourselves to the changing demographic balance in marriage markets. We suspect, however, that in other ways, too (ethnic intermarriage is an example), market inefficiencies have declined over time.

Table 5 presents indicators of the pace of marriage for a sample of 37 nonsouthern states. (We have excluded those states with heavy concentrations of rural blacks so as not to complicate our task of identifying inefficiencies in the marriage market.) In this table we selectively highlight primary marriage ages, citing the proportion of males married at 20-24 and 25-29 years and of females married at 20-24 years. The table displays the data (means and standard deviations for each age group) for 1890, 1920, 1940, and 1970. The year 1890 is the earliest point when data on marital status became available on a national level and is also the beginning of the slow secular decline in age at marriage; 1920 marks the period when this gradual decline abates; and 1940 marks the last prewar census date. Finally, 1970 brings the story reasonably near to the present. The figures, the reader 
should recall, are means based on state figures. They do not assign different weights according to the total population of the 37 states but, rather, treat the states themselves as units.

In our analysis we employ an age-specific sex ratio for the peak marriage ages (males 25-29/females 20-24) as a crude indicator of local marriagemarket variations. Surely, various refinements could be made in this measure, but it has the virtue of simplicity, and our objective here is merely to identify significant trends. ${ }^{10}$ For each sex, the ratio reveals local bulges in the population owing to domestic and international migration and, thus, the basis for local variation in sex ratio.

Table 6 presents for dates between 1890 and 1970 the Pearsonian correlation coefficients between the proportions of ever-married males 25-29 and females 20-24, and between both of these proxies for the pace of nuptiality and the age-specific sex ratio. In 1890 , the sex ratio was strongly correlated with the marriage probabilities of both men and young women: in states where men dominated the ratio, women were more prone to young marriage and the men were less prone. Although other local causes undoubtedly promoted positive correlations between the marriage proneness of the two sexes, these were outweighed in 1890 by marriage-market imbalances, and the correlation between male and female proportions married was significantly negative. By 1920 , this correlation had become weakly positive. The effect of sex-ratio variation upon marriage had diminished for both sexes, and other local conditions affecting marriage now prevailed. By 1940, this covariation was highly significant, and male marriage age was no longer correlated with the sex ratio, although the female marriage age still was. In attenuated form, this pattern persisted to 1970 .

Over time, the structural consideration of sex imbalances in local marriage markets ceased to be a factor in the "decision" of when to marry. We may well ask whether the disappearance of this once-potent factor was owing to a general homogenization in state sex ratios. ${ }^{11}$ There is, in fact, an unmistakable decline in the variance of the sex ratios (both in the 37 states as well as in large U.S. cities). The standard deviation of the state sex ratios was 0.538 in 1890 . It was more than halved to 0.155 by 1920 , halved again by 1940 to 0.073 , and was a mere 0.047 in 1970 . A regression analysis indicates

${ }^{10}$ Existing census materials would permit the computation of nonmarried sex ratios separately for native white, foreign-born white, and black populations (to reflect the segregation of marriage markets), with attention to urban/rural market segregation. Such refinements are perhaps premature before research on changes over time in the operation of marriage markets.

${ }^{11}$ To make sure that the pattern of observed state-to-state relationships was not entirely a function of small states with unusual population and marriage configurations, we examined the numbers of people in states lying beyond the $1 \mathrm{SD}$ point for sex ratio and proportions married. Indeed, the 1890 outliers on the high-sex-ratio, low-male-marriage side werre generally sparsely populated Western states. But from 1920, the extreme states took in large populations, who were affected by variations in the workings of the marriage market. 

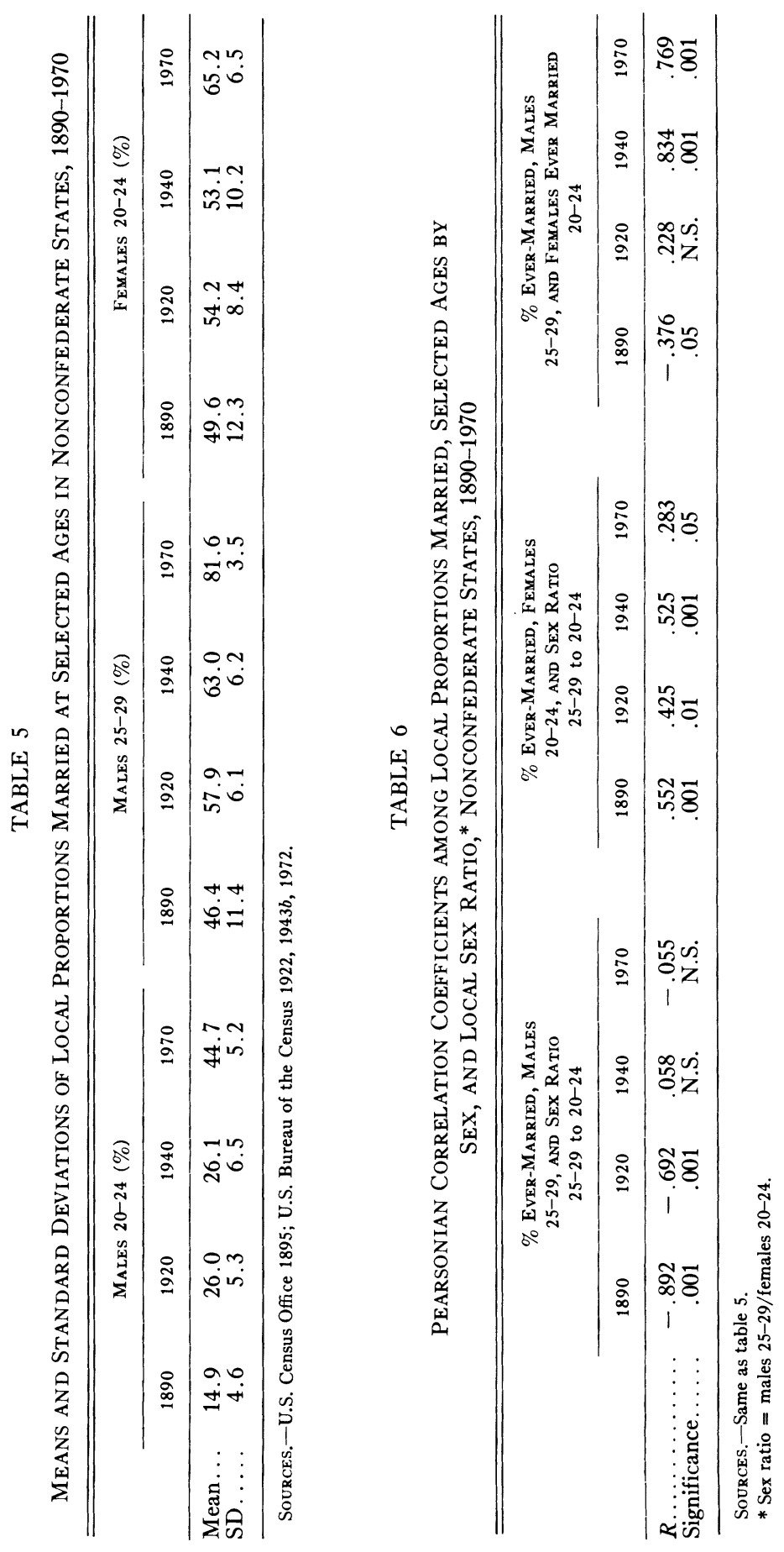
that, up to 1940 , this decline alone can explain the diminishing impact that sex-ratio imbalances had on age at marriage. However, more recently, in 1970, what little local variation remained in sex ratios no longer produced the effect on marriage age that would have been evident even a generation ago.

The basis for "decision" about marriage timing has changed, then, from involuntary to preferential, from a structurally constrained to an individually determined basis. Yet, the rationalization of the marriage market-at least as we have measured it here-had not led before World War II to a contraction of marriage spread. If, as literary evidence would lead us to expect, most people wished to marry in their early and middle twenties, ${ }^{12}$ why did not modality increase when marriage markets seemingly permitted more uniformity? We have only some possibilities to offer. One is suggested by the pattern of annual variation in nuptiality over the past century. Cycles were more placid in the late 19th century than in the early 20th, even before the extreme swings of the Great Depression (U.S. Department of Health, Education, and Welfare 1971, pp. 2-3). Postponements of marriage may have become more common in the early-20th century when economic prospects were favorable, resulting in a greater marriage spread. Alternatively, the "new immigration" may have imposed a greater degree of market segregation than had previously existed.

\section{Changes in the Relationship of Marriage and Headship}

As the traditional marriage-market effects on marriage age declined, other determinants replaced them. Part of the evolution toward this new pattern in the postwar period involved an altered relationship between the timing of marriage and other related transitions. The new basis for nuptial timing is part of a general reorganization in the sequence of family formation which begins with the relationship between marriage and household headship.

If we assume, as a casual examination of contemporary data might suggest, that the marriage transition implies a simultaneous transition into independent household status, we will miss an important element of historical change in family formation. While it is true that the greatest part of the timing of headship can be explained, at least in a statistical sense, by marriage, the two transitions are conceptually distinct. The extent to which there has been a pause between the two transitions has varied considerably over time. Though today they are usually accomplished simultaneously, even now a brief pause often separates marriage from headship.

12 This statement is based on an examination of late-19th-century popular fiction, newspaper writing, marriage manuals, and sermons, carried out by seminar students in 1975. None of these sources suggested that marriage ought to be deferred beyond the midtwenties for women or beyond the late-twenties for men. 


\section{Modell, Furstenberg, and Strong}

Table 7, reporting headship status over time, displays census data for 1890 through 1970. The figures reveal a gradual movement toward household formation at younger ages. Household headship became more nearly universal for the 35-44-year-old males, markedly more common for those at the most common marriage ages between 25 and 34 , and not so rare as once for the young men between 15 (or 14) and 24. In the most general terms, this pattern resembles the trend toward younger marriage. ${ }^{13}$

The two transitions were, however, far from perfectly related. In fact, age at marriage declined considerably more sharply than did age at headship, which seemingly was less flexible. (It may well be that in discussing headship we are also in an indirect way talking about the provision of housing, and housing is dependent on a wide variety of supply factors quite apart from demand.) By juxtaposing the headship and marriage rates we can derive an estimate, shown in table 8 , of the minimum proportion of married men at given ages who were not yet household heads. The actual proportion was

TABLE 7

\% Males Household Heads, By Age, United States, 1890-1970

\begin{tabular}{rrrrrrr}
\hline \hline \multicolumn{1}{c}{ Age } & 1890 & 1930 & 1940 & 1950 & 1960 & 1970 \\
\hline $14(15)-24^{*} \ldots \ldots \ldots$ & 9.0 & 11.4 & 10.6 & 14.7 & 16.3 & 16.2 \\
$25-34 \ldots \ldots \ldots \ldots$ & 57.8 & 62.4 & 62.2 & 69.4 & 76.5 & 77.7 \\
$25-29 \ldots \ldots \ldots \ldots$ & 49.4 & N.A. & 54.2 & 63.2 & N.A. & N.A. \\
$30-34 \ldots \ldots \ldots \ldots$ & 67.2 & N.A. & 70.7 & 75.9 & N.A. & N.A. \\
$35-44 \ldots \ldots \ldots \ldots$ & 77.8 & 80.3 & 79.5 & 81.2 & 85.8 & 86.4 \\
\hline
\end{tabular}

SourCES.-For 1890 and 1930, age distributions by sex (U.S. Census Office 1895, and U.S. Bureau of the Census 1933a) and age distributions of male household heads (U.S. Census Office 1896, and U.S. Bureau of the Census 1933c). For 1940 and later years, household status by sex and age data (U.S. Bureau of the Census $1943 b, 1953 a, 1964 a, 1973 a)$.

* 14-24 from 1950.

TABLE 8

Minimum Percentage* of CURRENTLY MARried Men Not HOUSEHOLd HEAdS, UNITED STATES, 1890-1970

\begin{tabular}{rrrrrrr}
\hline \hline Age & 1890 & 1930 & $1940 \dagger$ & 1950 & 1960 & 1970 \\
\hline $14(15)-24 \ddagger \ldots \ldots \ldots \ldots$ & 5.0 & 20.9 & 24.2 & 26.3 & 18.6 & 14.7 \\
$25-34 \ldots \ldots \ldots \ldots \ldots$ & 6.0 & 8.8 & 10.7 & 12.4 & 6.2 & 4.2 \\
$25-29 \ldots \ldots \ldots \ldots$ & 6.2 & $\ldots$ & 13.6 & 14.9 & $\ldots$ & $\ldots$ \\
$30-34 \ldots \ldots \ldots \ldots$ & 5.8 & $\ldots$ & 8.3 & 10.1 & $\ldots$ & $\cdots$ \\
$35-44 \ldots \ldots \ldots \ldots \ldots$ & 3.9 & 1.5 & 3.6 & 6.7 & 3.4 & 1.7 \\
\hline
\end{tabular}

Sources.- Same as tables 1 and 7.

* Assuming that there are no unmarried household heads.

$\dagger$ Married and spouse present.

† 14-24 from 1950 .

${ }^{13} \mathrm{~A}$ discussion of patterns for females here would be redundant insofar as it relates to our main argument, and considerably complicated owing to the tendency of widows to live in sub- or secondary families within households headed by others. 
somewhat higher. ${ }^{14}$ If anything, temporary coresidence of married children with parents - the extended household-was more likely in the first half of the 20th century than at the end of the 19th. Much of the pattern in 1950, of course, can be explained by the housing shortage which persisted until well after the end of the war. But this does not explain its persistence in 1930 and 1940 . As late as 1950, many young men were knowingly marrying into extended family situations, however temporary.

Because table 8 shows minima only, we present in table 9 the figures we can derive for the actual proportion of married men who were not household heads. As the estimates have led us to expect, the 19th-century pattern of a looser timing relationship between marriage and headship persists halfway into the current century. In more recent years, a far more precise sequencing predominates. The postwar pattern, to be sure, reflects previous preferences which often had to be held in abeyance for lack of resources. The 1940 census materials (U.S. Bureau of the Census 1943e, p. 33) show convincingly that among the segment of young marrieds the poor and unemployed most often failed to establish an independent residence. ${ }^{15}$ Even today, some young people who might wish to marry and establish an independent household still cannot afford to do so. The point is that now far more than in previous times the two transitions are supposed to be timed together.

Since at least 1940, then, marriage not closely followed by headship attainment was generally a product of an insufficiency of resources on the part of newlyweds. This led us to suspect that the increasing coordination of

TABLE 9

Percentage of Married Men Who are Household Heads, PhILAdelPhia, 1880, AND UNITEd STATES, 1940-1970

\begin{tabular}{cccccc}
\hline \hline Age & $\begin{array}{c}1880 \\
\text { (Phila.) }\end{array}$ & $1940 *$ & 1950 & 1960 & 1970 \\
\hline $14(15)-24 \dagger \ldots \ldots \ldots$ & Too few & N.A. & 71.4 & 79.6 & 83.3 \\
$25-34 \ldots \ldots \ldots \ldots \ldots$ & 82.9 & 83.9 & 86.3 & 92.7 & 94.5 \\
$35-44 \ldots \ldots \ldots \ldots$ & 91.2 & 89.4 & 91.4 & 95.1 & 96.3 \\
\hline
\end{tabular}

SouRCES.-1880 Philadelphia col. derived from computerized sample of individuals, enumerated by household, from enumerators' manuscripts of 1880 U.S. Census, at Philadelphia Social History Project, University of Pennsylvania; 1940 and later years from data on marital status by household status, age, and sex, in U.S. Bureau of the Census (1943a, 1953a, 1964a, 1973a).

* Spouse present.

† 14-24 from 1950.

${ }^{14}$ In 1950 , e.g., where the estimated minimum nonhead married proportion was $12.4 \%$ at $25-34$, the measured proportion was $13.7 \%$. This is because a number of men headed households without yet being married; but this number was traditionally small. Even today, when such practices are more common, relatively few single males are household heads.

${ }^{15}$ Data for Philadelphia and intercity comparisons in 1890 suggest that, on the other hand, in the 19th century, where parents could afford it and where houses were large enough, temporary coresidence after marriage was seemingly preferred by many younger couples, at least while childless. 
marriage and headship in the postwar period might be explained by a rapid diffusion of resources to younger segments of the population. Ideally, to test this explanation, we would want to examine the earning capacity of young couples over time, but income data are not available for various age, marital, and household-status combinations. Labor-force participation, however, can serve as a proxy for earning capacity. Our expectation was not borne out. Labor-force participation of married household heads was nearly universal before 1940 even among the extremely young. If anything, the economic position of young married males has become less independent in recent decades.

Further evidence pertaining to this hypothesis is presented in table 10, which provides figures on the headship status of young married males who were and who were not in the labor force. These data allow us to determine whether the greater degree of simultaneity between marriage and household headship was occasioned by a closer coordination between marriage and entrance to the labor force. The table clearly shows that the tie between marriage and labor-force participation has become less crucial than was once the case. Regardless of their employment status, most married men today are more likely to be household heads. The waning tie between labor-force entry and the transition to marriage and household headship obviously cannot be explained by a diminished need for resources. Wherewithal surely is still required to afford an independent household. But young couples have been able to find resources elsewhere-often no doubt from wife's earnings but sometimes, too, from parental loans or contributions. The increasingly modal timing of marriage and the growing expectation of a prompt sequencing of marriage and headship required other flexibilities. In order to achieve these ends, couples have been prepared to innovate, sometimes in ways formerly unavailable or unacceptable.

Thus, new patterns were created, and older ones disappeared. Temporary coresidence of married couples with parents, long a source of flexibility,

TABLE 10

Percentage of Married-Spouse-Present Men Who Are Household Heads, by Age and Labor-ForCe Status, United States, 1940-1970

\begin{tabular}{|c|c|c|c|c|c|c|c|c|}
\hline & \multicolumn{4}{|c|}{ Married Men in Labor Force } & \multicolumn{4}{|c|}{ Married Men Not in Labor Force } \\
\hline & 1940 & 1950 & 1960 & 1970 & 1940 & 1950 & 1960 & 1970 \\
\hline $\begin{array}{r}14-17 \ldots \ldots \\
16-19 \ldots \ldots\end{array}$ & 50.3 & $\begin{array}{l}45.7 \\
\ldots\end{array}$ & $\begin{array}{c}63.4 \\
\ldots\end{array}$ & 82.3 & 15.8 & $\begin{array}{c}12.3 \\
\ldots\end{array}$ & $\begin{array}{c}26.7 \\
\ldots\end{array}$ & 72.8 \\
\hline $\begin{array}{r}18-24 \ldots \ldots \\
20-24 \ldots \ldots\end{array}$ & 75.5 & 79.1 & 90.6 & 94.6 & 42.3 & 66.4 & 77.5 & 88.0 \\
\hline $25-34 \ldots \ldots$ & 95.0 & 90.9 & 97.3 & 98.6 & 64.3 & 78.3 & 91.5 & 94.8 \\
\hline
\end{tabular}

SourCE.- Marital status by labor-force status, age, and sex in U.S. Bureau of the Census (1943e, 1953b, $1963,1973 d)$. 
became less frequent. Once a strategy for easing the economic demands of marriage, family extension became a mildly deviant arrangement. ${ }^{16}$ Table 11 provides an estimate of the prevalence of "doubling up" (newlyweds who lived with their families for a time after marriage) over time. The percentages shown are of the currently married who are living with their own parents (both spouse present and spouse absent), subdivided into age groups. (We can assume that the figures here should be roughly doubled if our criterion for family extension was residence with either set of parents.) The pattern is clear. At each point in time a relatively high proportion of the youngest married men live with their parents. Coresidence was actually more common in 1947 than in Philadelphia in 1880. Yet by late-19th-century standards, coresidence was high in Philadelphia because single-family housing was plentiful in the city. Only after 1947 did the prevalence of family extension decline, and it declined abruptly. ${ }^{17}$

Extension, at least insofar as it has affected newlyweds, has not been a historical constant. Whether or not we wish to regard the decline of the practice of "doubling up" as a significant departure in the history of American kinship, we cannot completely ignore its implications for family life. Even if coresidence was experienced only briefly by most people, it commonly affected newlyweds at a critical juncture in their lives and at a time in which significant patterns of interaction were being formed. As we have seen, 19th-century levels of extension persisted into the very recent past; and, as with the timing of marriage, World War II marks a dividing line between an earlier form of behavior and the one that many have come to believe has long been with us. ${ }^{18}$

${ }^{16}$ In this respect as in many others, black families now resemble 19th-century families in their form and strategies. In 1970, regardless of the age of their heads, about three times the proportion of black families as of white were extended. The stigma now attached to this accommodation has a nice irony, considering how common it was in the white population only a generation ago (U.S. Bureau of the Census 1973c, pp. 237-38).

${ }^{17}$ We have three sets of data bearing upon the question of independent residence for young couples, which include information on interval since marriage. These data are from Philadelphia in 1880, which we will assume to stand well enough for 19th-century urban behavior (probably on the high side of coresidence with parents); from a Current Population Survey taken in April 1948 (U.S. Bureau of the Census 1948) near the height of the postwar marriage boom; and from the decennial census of 1970. Each shows a sharp gradient toward independent residence as length of marriage increases. In 1948 when the housing squeeze was intense, no fewer than one-third of all who married within the year, of whatever age, were not yet household heads. In 1970 as in 1880, the proportions were lower, but even for 1970 the proportions without their own households among those who had recently married was high enough to allow us a rough guess that one in five or so contemporary grooms live for a while outside of their own households, most typically in extended families. The estimate we might derive from 1880 was that about one-third experienced extension at some time. Viewed longitudinally, headship attainment is considerably more complex a process than it would seem from cross-section alone.

${ }^{18}$ Once again we owe an intellectual debt to Monahan, who in a brief note (1956) recognized but made little of this historical fact. 


\section{Modell, Furstenberg, and Strong}

\section{Marriage and Parenthood}

The life-course transition marked by the birth of one's first child is closely connected with the transitions into marriage and into independent household status. In the timing of fertility, as in the timing of headship, added resources -in this instance contraceptive technology-have potentially permitted a wider range of timing choices. In the past, conception and marriage typically

\section{TABLE 11}

Percentage of Married People Living in OWn Parents' Households, by Age, Sex, and Presence of Spouse, Philadelphia, 1880, AND UNITED STATES, 1947-1970

\begin{tabular}{|c|c|c|c|c|c|}
\hline & $\begin{array}{c}1880 \\
\text { (Phila.) }\end{array}$ & $\begin{array}{c}1947 \\
\text { (Civilian } \\
\text { Population) }\end{array}$ & 1950 & 1960 & 1970 \\
\hline & \multicolumn{5}{|c|}{ All } \\
\hline $\begin{array}{l}\text { Males: } \\
14-17 \ldots \ldots \ldots \ldots \\
18-24 \ldots \ldots \ldots \ldots \\
25-34 \ldots \ldots \ldots \ldots \\
35-44 \ldots \ldots \ldots \ldots\end{array}$ & $\begin{array}{r}\overline{12.1} \\
4.8 \\
.8\end{array}$ & $\begin{array}{r}47.4 \\
14.5 \\
5.6 \\
1.4\end{array}$ & $\begin{array}{r}39.5 \\
10.5 \\
3.6 \\
1.4\end{array}$ & $\begin{array}{r}52.3 \\
6.7 \\
2.0 \\
.9\end{array}$ & $\begin{array}{r}23.4 \\
5.3 \\
1.2 \\
.6\end{array}$ \\
\hline $\begin{array}{l}\text { Females: } \\
14-17 \ldots \ldots \ldots \ldots \\
18-24 \ldots \ldots \ldots \ldots \\
25-34 \ldots \ldots \ldots \ldots \\
35-44 \ldots \ldots \ldots \ldots\end{array}$ & $\begin{array}{r}44.4 \\
12.3 \\
4.2 \\
1.5\end{array}$ & $\begin{array}{r}24.0 \\
15.4 \\
6.1 \\
2.0\end{array}$ & $\begin{array}{r}21.4 \\
9.3 \\
6.3 \\
2.1\end{array}$ & $\begin{array}{r}22.5 \\
6.7 \\
2.3 \\
1.2\end{array}$ & $\begin{array}{r}21.8 \\
6.5 \\
1.6 \\
.8\end{array}$ \\
\hline & \multicolumn{5}{|c|}{ Living with Spouse } \\
\hline $\begin{array}{l}\text { Males: } \\
14-17 \ldots \ldots \ldots \ldots \\
18-24 \ldots \ldots \ldots \ldots \\
25-34 \ldots \ldots \ldots \ldots \\
35-44 \ldots \ldots \ldots \ldots\end{array}$ & $\begin{array}{l}\text { N.A. } \\
\text { N.A. } \\
\text { N.A. } \\
\text { N.A. }\end{array}$ & $\begin{array}{r}52.9 \\
12.7 \\
4.7 \\
1.0\end{array}$ & $\begin{array}{r}32.3 \\
8.3 \\
2.7 \\
.9\end{array}$ & $\begin{array}{r}21.2 \\
4.3 \\
1.1 \\
.4\end{array}$ & $\begin{array}{r}8.4 \\
3.1 \\
.6 \\
.2\end{array}$ \\
\hline $\begin{array}{r}14-17 \ldots \ldots \ldots \ldots \\
18-24 \ldots \ldots \ldots \ldots \\
25-34 \ldots \ldots \ldots \ldots \\
35-44 \ldots \ldots \ldots\end{array}$ & $\begin{array}{l}\text { N.A. } \\
\text { N.A. } \\
\text { N.A. } \\
\text { N.A. }\end{array}$ & $\begin{array}{r}15.2 \\
12.0 \\
4.3 \\
1.4\end{array}$ & $\begin{array}{r}13.2 \\
6.5 \\
3.2 \\
1.5\end{array}$ & $\begin{array}{r}7.9 \\
2.6 \\
.9 \\
.5\end{array}$ & $\begin{array}{r}7.2 \\
1.9 \\
.5 \\
.2\end{array}$ \\
\hline $35-44 \ldots \ldots \ldots$ & \multicolumn{5}{|c|}{ Living Apart from Spouse } \\
\hline Males: & & & & & \\
\hline $\begin{array}{l}14-17 \ldots \ldots \ldots \\
18-24 \ldots \ldots \ldots \ldots \\
25-34 \ldots \ldots \ldots \ldots \\
35-44 \ldots \ldots \ldots \ldots\end{array}$ & $\begin{array}{l}\text { N.A. } \\
\text { N.A. } \\
\text { N.A. } \\
\text { N.A. }\end{array}$ & $\begin{array}{l}0 \\
48.7 \\
34.1 \\
17.3\end{array}$ & $\begin{array}{l}49.9 \\
36.9 \\
20.5 \\
11.2\end{array}$ & $\begin{array}{l}81.1 \\
27.7 \\
19.6 \\
12.4\end{array}$ & $\begin{array}{l}68.2 \\
23.8 \\
17.6 \\
10.6\end{array}$ \\
\hline $\begin{array}{l}\text { Females: } \\
14-17 \ldots \ldots \ldots \ldots \\
18-24 \ldots \ldots \ldots \ldots \\
25-34 \ldots \ldots \ldots \ldots \\
35-44 \ldots \ldots \ldots \ldots\end{array}$ & $\begin{array}{l}\text { N.A. } \\
\text { N.A. } \\
\text { N.A. } \\
\text { N.A. }\end{array}$ & $\begin{array}{l}71.0 \\
58.0 \\
37.4 \\
16.7\end{array}$ & $\begin{array}{l}70.5 \\
50.6 \\
29.0 \\
13.1\end{array}$ & $\begin{array}{l}72.1 \\
48.0 \\
25.4 \\
20.5\end{array}$ & $\begin{array}{l}67.3 \\
44.0 \\
18.2 \\
10.7\end{array}$ \\
\hline
\end{tabular}

SourCES.-1880 Philadelphia, same source as table $9 ; 1947$ and subsequent years marital status by household status, age, and sex, in U.S. Bureau of the Census, Current Population Survey, no. 10; and same as table 9. Note.-Insufficient cases are denoted by - -

\section{S138}


were linked closely, with either one of these events closely following the other.

The rarer of the two sequences, beginning with premarital pregnancy, no doubt influences the timing of marriage, though it is not easy to calculate the precise effects of premarital conceptions on nuptial timing. Premarital sexual activity seems to have sharply increased after the Second World War, contributing to far larger numbers of "forced" marriages (Smith 1973). The decision to marry was for quite a substantial number of marriers preempted by earlier and less considered choice. The abrupt postwar departure from past patterns of marriage timing thus included an element of increased individual control over sexuality.

In the more common sequence, in which marriage precedes conception, anticipated childbirth is a less direct but no less important determinant of marriage timing. The expectation of prompt childbirth undoubtedly influenced the decision of when to marry. As long as the interval between marriage and first birth was more or less fixed, there had to be greater flexibility in the staging of transitions related to marriage. (We have already seen how the integration of marriage and headship was eased early in the 20th century in order to "purchase" a slightly lower age at marriage.) The 20th-century emergence of flexibility in the period between marriage and first birth drastically altered the trade-offs customarily made in the process of family formation. In this respect, at least, the increasing availability of contraception bears analogy to the more efficient operation of the marriage market and the rapid expansion of available housing, both of which served to remove preexisting structural constraints on the marriage decision, thus making nuptial timing more responsive to individual preference.

Evidence to this effect is presented in table 12, which shows the very large changes that occurred in the percentage of all women, 20-24 or 25-29 and married less than three years, who had given birth to at least one child. The age groups vary together closely and change a great deal from date to

TABLE 12

Percentage of Women, by Age, Bearing First ChILd Within Three

YEARS OF MARRIAGE, 1910-1970, AND WITHIN ONE AND

TWO YEARS OF MARRIAGE, 1950-1970, UNITED STATES

\begin{tabular}{|c|c|c|c|c|c|c|}
\hline \multirow[b]{3}{*}{ Census } & \multicolumn{3}{|c|}{ Age at Census 20-24 } & \multicolumn{3}{|c|}{ Age at Census 25-29 } \\
\hline & \multicolumn{3}{|c|}{ Married (Years) } & \multicolumn{3}{|c|}{ Married (Years) } \\
\hline & $1-2$ & $2-3$ & 3 or Less & $1-2$ & $2-3$ & 3 or Less \\
\hline $\begin{array}{l}1910 \ldots \ldots \ldots \\
1940 \ldots \ldots \ldots \\
1950 \ldots \ldots \ldots \\
1960 \ldots \ldots \ldots \ldots \\
1970 \ldots \ldots \ldots \ldots\end{array}$ & $\begin{array}{l}\text { N.A. } \\
\text { N.A. } \\
39.1 \\
61.8 \\
30.7\end{array}$ & $\begin{array}{l}\text { N.A. } \\
\text { N.A. } \\
59.5 \\
79.9 \\
53.8\end{array}$ & $\begin{array}{l}53.3 \\
37.7 \\
41.3 \\
56.1 \\
36.7\end{array}$ & $\begin{array}{l}\text { N.A. } \\
\text { N.A. } \\
36.7 \\
55.5 \\
31.0\end{array}$ & $\begin{array}{l}\text { N.A. } \\
\text { N.A. } \\
54.4 \\
71.0 \\
47.1\end{array}$ & $\begin{array}{l}45.9 \\
32.0 \\
40.8 \\
54.2 \\
37.0\end{array}$ \\
\hline
\end{tabular}

Source.-Retrospective reports on fertility from U.S. Bureau of the Census (1947, 1955b, 1964c, 1973f). 
date. In 1910, more than half the wives 20-24 years old married less than three years (i.e., with an average marriage duration of 18 months) had borne a child. The likelihood, then, was for relatively rapid childbirth. The change between 1910 and 1940 was a large one, probably indicating a more widespread knowledge of contraception as well as a hesitant climate for childbearing in the uncertain economic setting of the depression. These factors outweighed likely gains in fecundability. It seems at least possible, then, that part of the prewar 20th-century decline in marriage age was due to an increased independence of the timing of marriage from the timing of the first birth. ${ }^{19}$

Between 1940 and 1960, a rapid shortening of the interval between marriage and first birth took place, approaching the patterns set in 1910. Only a part of this shift can be accounted for by the rising rates of premarital pregnancy. Changing preferences seem to have dictated the rest. Given the choice, most young married couples once again virtually merged the two transitions. The equally rapid shift between 1960 and 1970 back toward the 1940 pattern shows that this aspect of the larger change was a relatively temporary phenomenon. As preferences increasingly prevail in the timing of family building, rapid fluctuation becomes more possible and, we suspect, more likely.

The postwar period brought a sharp decline in the median age of first birth due in part to a much reduced marriage age for women but also, as we have seen, to a greater proclivity for a closer articulation between marriage and childbearing. The transformation that occurred in the age of females at the birth of their child, and its relationship to changes in marriage age, is shown in table 13. The increase in age at first birth between 1928 and 1948 , along with the concurrent slow decline in marriage age, reflects the

TABLE 13

Median, First and Ninth Deciles, and Spread of Age OF MOTHER AT FIRST CHILDBIRTH, SELECTED YEARS 1917-1970, UNited States REgistration AREA

\begin{tabular}{lcccc}
\hline \hline & $\begin{array}{c}\text { Median } \\
\text { Age }\end{array}$ & $\begin{array}{c}\text { First } \\
\text { Decile }\end{array}$ & $\begin{array}{c}\text { Ninth } \\
\text { Decile }\end{array}$ & Spread \\
\hline $1917 \ldots \ldots \ldots \ldots$ & 22.8 & 17.1 & 29.7 & 12.6 \\
$1928 \ldots \ldots \ldots$ & 21.9 & 17.8 & 29.4 & 11.6 \\
$1938 \ldots \ldots \ldots$ & 22.4 & 18.0 & 29.9 & 11.9 \\
$1948 \ldots \ldots \ldots$ & 22.5 & 18.1 & 30.4 & 12.3 \\
$1954 \ldots \ldots \ldots$ & 22.0 & 17.8 & 29.9 & 12.1 \\
$1960 \ldots \ldots \ldots$ & 21.1 & 17.5 & 28.2 & 10.7 \\
$1970 \ldots \ldots \ldots$ & 21.3 & 17.4 & 27.1 & 9.7 \\
\hline
\end{tabular}

Sources.-Age of mother at first childbirth data from U.S. Department of Health, Education, and Welfare, Vital Statistics of the United States (various dates).

* Based, unlike the other years, on five-year age categories.

19 We would of course prefer to compare fertility experience around 1890 to that in 1920 in order to establish this point. Regrettably, these data are not available in aggregate form. 
greater conscious delay of the first birth. ${ }^{20}$ In addition, the modality of age at first birth had greatly increased by 1960. The transition to parenthood was becoming increasingly age graded, just as was marriage. (Interestingly enough, the tendency toward increasing uniformity remained strong at least through 1970, despite the decline in the birth rate during this period, which might well have resulted in a widening of the spread in the age at first birth.)

The postwar movement toward greater modality in the period between marriage and first birth has two components. The first, as we have seen, is a movement toward a more standard interval between marriage and first birth. But a second and equally important development is the growing trend for late and early marriers to behave similarly. Before 1940, age at marriage was significantly related to the length of the interval between marriage and childbirth. As is shown in table 13, in 1910 young marriers were prompter childbearers than those who deferred marriage. The pattern disappeared by 1970. ${ }^{21}$ Predictably enough, this change took place between 1940 and 1950.

A more extensive view of the same phenomenon is shown in table 14 . The numbers represent the difference between those 20-24 and 25-29 in percentage of those still childless, at given marriage durations. Generally, the differences dwindle after the war, following increases between 1910 and 1940 . Viewed from this perspective, we see that the general hesitation about committing oneself to childbirth that obtained in 1940 did nothing to erase the strong relationship that had been present, at least in 1910, between age at marriage and first childbirth. Indeed, this association was strengthened

TABLE 14

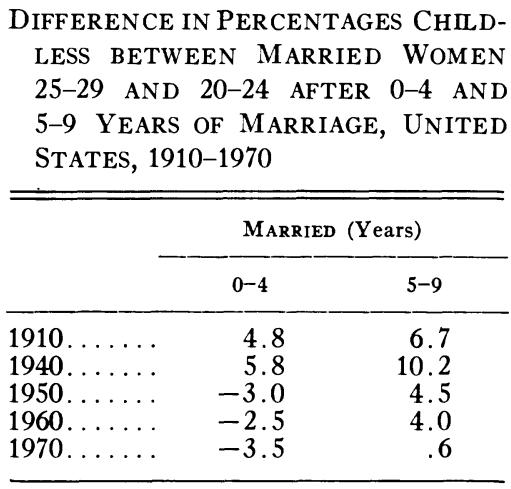

Sources.-Same as table 12.

${ }^{20}$ The 1917 figure perhaps belies this observation. The data upon which the figure is based, however, may be faulty in that they alone are tabulated by five-year age groups. The only 19th-century data that we know to exist concerning age of mother at first birth are from Michigan in 1884 and 1894. These are published in one-year age groups and show spread figures closer to 1928 than to 1917.

${ }^{21}$ We omit the youngest mothers from consideration here because so many in this category have had premarital conceptions. 


\section{Modell, Furstenberg, and Strong}

by comparison with 1910 . Prior to World War II, it would seem, the timing of marriage set the terms of other familial events. Age at marriage was an important career contingency, affecting the pace of the transition to parenthood. But, after the war, marriage age ceased to have a continuing effect on the timing of parenthood. As never before, the matrimonial decision, itself, now subsumed one's past.

\section{Marriage and Female Labor-Force Participation}

The slight decline in marriage age in the first half of the 20th century can be seen as partially facilitated by two transformations: the continuing acceptability of coresidence with kin, and the ability and desire to delay childbearing after marriage. To some extent, certain components of the transition to adulthood (independent residence, the rapid movement to childbearing) were for a time subordinated to young marriage. Though initially a housing shortage inhibited the establishment of uniform sequence of family formation in the postwar period, soon a rapid expansion of the housing stock and the continuation of a delay between marriage and first birth allowed most to follow the trend toward more uniform marriage ages.

At least one more feature of the life course was modified, as table 15 shows,

TABLE 15

Percentage of Married Women in Labor Force by Age and ChILdBearing Status, United States, 1890-1970

\begin{tabular}{|c|c|c|c|c|}
\hline & \multicolumn{4}{|c|}{ Age of Woman } \\
\hline & $14-19$ & $20-24$ & $25-29$ & $30-34$ \\
\hline \multicolumn{5}{|l|}{$1890:^{*}$} \\
\hline All:. & 2.2 (at 15-24) & & 2.5 & 2.4 \\
\hline $1920:^{*}$ & & & & \\
\hline All... & 12.5 (at $15-19)$ & 11.4 & 9.7 (at 25-34) & $\cdots$ \\
\hline $\begin{array}{l}\text { 1940: } \dagger \\
\text { Nonmothers. }\end{array}$ & N.A. & 27.3 (at $18-24$ ) & 35.9 & 31.2 \\
\hline Mothers........ & N.A. & 6.4 (at $18-24)$ & 8.7 & 8.8 \\
\hline \multicolumn{5}{|l|}{$1950: \ddagger$} \\
\hline $\begin{array}{l}\text { Women with no child } \\
\text { under } 10 \ldots \ldots \ldots\end{array}$ & 31.3 (at 15-19) & 54.2 & 53.8 & 49.0 \\
\hline $\begin{array}{l}\text { Women with children } \\
\text { under } 10 \ldots \ldots \ldots \ldots \\
1960: \ddagger\end{array}$ & 10.4 & 13.9 & 15.3 & 18.2 \\
\hline Nonmothers.......... & 37.3 & 63.5 & 66.3 & 72.4 \\
\hline \multirow{2}{*}{\multicolumn{5}{|c|}{$1970: \ddagger$}} \\
\hline Nonmothers. & 43.5 & 71.1 & 72.4 & \\
\hline Mothers....... & 26.2 & 34.0 & 34.2 & 39.2 \\
\hline
\end{tabular}

SoURCES.-U.S. Bureau of Census (1907, 1923, 1943d, 1955b, 1963, 1973d).

* Native whites of native parentage; "breadwinner" definition of labor-force participation.

$\dagger$ All married women with husbands present.

$\ddagger$ All married women. 
in the process of achieving a younger marriage age-that of married female participation in the labor force. One striking feature of the table is the constant but decreasing difference in labor-force participation between wives with and without children. But more important as a determinant of marriage age is the (re)invention, since 1890, of the working wife. Like the growing gap between marriage and first birth, the possibility of employment for married women increased the flexibility of timing choice for young people who were contemplating matrimony. Once again, the decade in which the transformation is most evident is the crucial World War II decade. For 20-24-year-old women, the age group in which the marriage surge was concentrated, an enormous increase occurred in labor-force participation, an increase which has not subsided even to date.

\section{Conclusion}

Seen from a life-course perspective, we have argued that important features of the 19th-century pattern of family formation in the United States lasted at least until World War II. Despite such widely recognized changes in family-related behavior as the gain in income per capita, the completion of the demographic transition, the steady extension of school careers, and the emergence of a postparental period, young men and women typically left their parents' homes, married, and set up their families over very nearly the same parts of their lives in 1940 as they had for the previous half-century.

During the war and in the postwar period, the timing of marriage and its relationship to other transitions altered markedly. Once in place, the postwar pattern itself was surprisingly persistent, though we are forever catching distant early warnings of its cracking: widespread premarital cohabitation, increased single farenthood among the young, a new valuation for "childless" marriage, and a return to more complex household forms. We offer no prognostications but wish to reiterate that we have observed, using varied and sufficiently reliable sources of data, that abrupt change followed a relatively lengthy period of stasis. It could well happen again.

We have located a significant historical transformation in the American family but have not provided a satisfactory explanation for the changes which have been depicted. To do so would require a detailed chronology of the wartime and postwar transition in marriage age, with attention to local variations. With due appreciation for the complexities of providing this sort of account, we shall conclude by sketching some of the considerations that may have figured in the transformation. Our interpretation takes into consideration both changing structural conditions and alterations in preferences in the postwar period, events which may have helped to dislodge the pattern of family formation carried over from the previous century.

The Great Depression was severe enough and long enough that, unlike 
previous cyclicalities, the age structure of marriage was altered. Careers were not merely temporarily delayed but were reoriented. ${ }^{22}$ Beginning with the c'epression and continuing for a decade or more, both marriage and childbearing generally became problematic. Perhaps half a generation of youth thus were cut loose from traditional timing criteria, long enough for the criteria themselves to shift. ${ }^{23}$ As early as 1940, established patterns of family formation were breaking down as young people anticipated the outbreak of war and the economic crest that so typically accompanies armament. Marriage became what one commentator called "the war disease." The reasons for this are various: some calculatively economic, some unabashedly romantic, some involving the innovation of new patterns while pursuing the logic of existing norms. "If we wait until the men come back after this war lasts several years, they'll pass us up for younger women," reasoned one Ohio respondent to a question about war marriages. "You can depend on it," said another. "Men just go for widows, grass or sod, better than a chilly virgin." ${ }^{24}$

Toward the end of the war, a certain degree of uneasiness was reflected in the family literature as to whether servicemen might have lost the necessary "domestic skills" to maintain stability in the family. The enormous surge of marriages in the early postwar period provided reassurance that men had not lost their taste for matrimony. While there was an active campaign for marriage education in the schools, the church, the home, and the office of the marriage counselor, marriages contracted at ages that once would have seemed too young were rarely condemned in the postwar period. Experts expressed confidence, however, that the marriage rush was a temporary phenomenon. They were wrong. ${ }^{25}$

We do not believe that wartime experience as such permanently changed marriage preferences and thereby marriage practices, though it must be regarded as at least a logical possibility. A more theoretically compelling explanation would detail underlying structural alterations. The present

${ }^{22}$ Bernard's (1940) perceptive treatment of the effect of the depression on age at marriage seems to assume that the kind of change she found in the $1930 \mathrm{~s}$ - a postponement specifically of younger marriages - was typical in cyclical movements. Our close examination of Massachusetts, Michigan, and Philadelphia marriage-registration data convinces us of the exact opposite: in altering the age schedule of marriage, the depression was unique among American fluctuations.

${ }^{23} \mathrm{As}$ Waring (1975) indicates, one of the social responses to imbalance between roles and available candidates is "changing the age criteria" for these roles.

${ }^{24}$ Throughout the war, the popular literature and writings of family-study professionals was preoccupied with the question of the desirability of war marriages, the number of which soared, though generally sympathies ran high for the young couple who wished to gain some measure of "personal security as the sea of crisis runs high" (Panunzio 1943; Robbins 1944).

${ }^{25}$ In 1946, Glick characterized the rush as a " 'borrowing' of marriages from the future" (p. 240), while Davis (1950) soon thereafter anticipated a low marriage rate in the 1950s, despite favorable economic prospects, "because a large portion of the marriageable population has been, so to speak, used up in the matrimonial marathon of the 1940's" (p. 10). 
paper cannot pretend to isolate these, but it seems likely that some combination of three dimensions are at the heart of the changing pattern of family formation: shifts in the degree of age grading, rearrangements in the family economy examined over the family life cycle, and new institutional bases for life-course decisions.

Age grading in American society has tightened significantly in two respects, both of which imply closer coordination in the timing of behaviors (like marriage) among age peers. Despite the expansion of higher education and the lengthening of educational careers, school departure has nonetheless become more modal. Between 1940 and 1950 more young people stayed in school until high school graduation and seem to have done so at a rather more uniform age, even though the educational attainment generally became more varied within successive cohorts during this same period (Rockwell 1976). Thus, the percentage of males, $18-20$ years of age, who had ceased their education after four years of high school was $27.5 \%$ in 1940 and $32.3 \%$ in $1950 .{ }^{26}$ Moreover, for young men, the wartime and peacetime conscription (or at least the possibility of it) was a powerful agency for creating cohort self-consciousness. ${ }^{27}$ (The peacetime draft, of course, is over; the constraints that structure lives continue to change.)

The 19th-century family economy, as we have noted, typically took a cooperative form at various stages in the family life cycle. From one point of view, this was no less true after World War II than before-despite the proliferation of new families. The proportion of urban families with two or more members in the labor force remained around $32 \%$ in 1930 and 1940, rose to $34.5 \%$ in 1950 , and then to $43.8 \%$ in 1960 and $52.1 \%$ in 1970 (U.S. Bureau of the Census 1943g, p. 36; 1955a, pp. 2A-31; 1964b, pp. 5-9; 1973e, p. 13). A 1947 Current Population Survey inquiry into the subject showed virtually identical distributions of husband-wife families by numbers in the labor force in 1947 as in 1940 (U.S. Bureau of the Census 1946-1947, no. 10, pp. 6-7).

Yet looked at more closely, a shift was taking place within this continuing

${ }^{26}$ From level of education by age data and cross-sectional enrollment-by-age data (see U.S. Bureau of the Census 1943c, 1953c).

${ }^{27}$ The conjunction of the draft, school-departure timing, and the timing of marriage is treated in a thought-provoking way by Winsborough $(1975,1976)$ in a series of unpublished papers based on recent longitudinal and retrospective data. Winsborough speculatively emphasizes the effects of the draft on the higher male marriage modality and greater youthfulness in the postwar period, and argues that cohort-by-cohort variation in this period can be explained by the effects of cohort variation in military service, working through age-specific probabilities of marriage in and out of the service. This, Winsborough suggests, can have operated virtually independently of any changes in preference. Indeed, Winsborough's model fits the postwar period rather neatly, despite its exclusive focus on male experience. We doubt, though, that it could alone explain the sharp transformation which took place in the decade of the forties. Indeed, the age-specific marriage patterns Winsborough's model presupposes are postwar, and are themselves products of the melodrama and underlying structural changes we are discussing. 
facade of economic collaboration. We suspect that this change reflected and in part contributed to the demarcation of generational units. Specifically, married women participated in the labor force, as it were, in place of children, who now stayed in school longer, or left their families of orientation to establish their own households. Comparing young adult participants in the labor force in 1940 and 1950, we find two dramatic shifts. The number of single male relatives of heads 18-24 (typically sons) who worked was about halved in the decade, while the number of young working wives more than doubled. The increase of working wives, as we have seen, was directly associated with earlier establishment of household headship.

These patterns are quite complex, and no descriptive account-certainly not one so sketchy as ours-can untangle the labor-market and familyeconomy considerations that went into the marked reordering of priorities reflected in these figures. The critical conclusion, however, seems unmistakable: a changing and again vibrant economy made available the jobs that permitted a novel integration of work and family roles, a manifestation of which was the postwar age-at-marriage pattern. ${ }^{28}$

A final aspect of family economy is far harder to get at but has the advantage of leading us toward institutional changes. The prewar collaborative family depended, especially in times of distress, on the economic contributions of adult offspring, who typically remained in the home. Under postwar conditions, however, when prosperity made young people residentially independent at an earlier age, the direction of economic dependency may have reversed (on net, that is, for exchanges in both directions still exist and no doubt always have) (Hill 1970). A charming piece of historical ethnography, we suspect, would be to recreate the development (in the postwar period, probably) of the variety of ritual falsehoods by which parents subsidized the marriages of their children, who would have been both too young and too dependent to marry by the standards of an earlier generation.

The overall effect of institutional change in the war decade, apparently, was to redistribute benefits in an age-specific manner, with the consequence of promoting earlier and more modal marriage patterns. The most obvious of such institutional innovations were the G.I. Bill of Rights and Social Security. The redistributions affected by both of these governmental innovations increased decision-making flexibility and thus had an impact

\footnotetext{
${ }^{28}$ Moreover, we suspect that not only were the performers of work roles changing in a way that altered the pattern of family formation, but also the jobs available to young people influenced the transition from the family of orientation to the family of procreation. The occupations which provide stable, predictable careers appeared to increase over the 1940s and in many cases to be available to new entrants to the labor force. This age group also seems to have improved their average annual earnings at an especially lively pace over the period, and these earnings improvements may well have been invested in the establishment of independent households. Again, these observations are tentative and call for far more intensive analysis, fortunately of data that exist in profusion (U.S. Bureau of the Census, Current Population Survey, P-60, annually; U.S. Bureau of the Census 1943f).
} 
analogous to that of contraception or female employment. Each seemingly removed barriers to marriage. The G.I. Bill essentially allowed veterans to pass rapidly through a number of transitions which previously would have required an extended period, ${ }^{29}$ while the Social Security System hastened the movement away from the 19th-century collaborative family economy by freeing young people, at least in part, from the burden of caring for their elderly kin. ${ }^{30}$

From the perspective of the individual, the postwar period appeared to pose fewer impediments to arranging the life course ad lib. ${ }^{31}$ As individuals gained the resources to schedule decisions according to their own personal timetables, they did so more uniformly than before. From the vantage point of any cohort, at least after the immediate postwar period, life-course choices became more modal. We do not wish to insist, however, that the new timing of marriage inevitably bound the individual into a more determinate conjugal career than was the case in previous times. A more prescribed course of family formation did not preclude subsequent flexibility in the familial career. Perhaps, as Ryder (1969, p. 116) suggests with regard to fertility, the new modality of family formation will increasingly bind cohort histories to "questions of fluctuation rather than of trend."

In this paper we have kept narrowly to first entrance to the married state, ignoring divorce. We suspect that our discussions of modality and timing would have been considerably different, reversed perhaps, if our concern were not first but final marriage. And, lest our argument create another

${ }^{29}$ The original bill provided one year of schooling for veterans who had served 90 days and who were not older than 25 at time of entry. In addition, it provided one year of schooling for every year of service up to a maximum of four subsidized years. The bill provided for payment of fees, tuition, books, and supplies, and carried a monthly subsistence payment of $\$ 50$ for single veterans and $\$ 75$ for married veterans. Both payments were soon increased. Home, farm, and business mortgages were easily and generously financed under the G.I. Bill. Fully $\$ 14.5$ billion was transferred to veterans under the various titles of the G.I. Bill, affecting more than 7.5 million veterans (Olson 1974).

${ }^{30}$ The influence of the Social Security System on the timing of marriage can best be seen as part of a larger long-term shift that led to greater economic independence of older people from those younger. Changes in intergenerational transfers are hard to document, but beginning in about 1950 older people began to receive increasing sums from extrafamilial sources. Expressed in constant 1966 dollars, average income for a married couple on Social Security rose from $\$ 1,720$ in $1941-42$, to $\$ 1,930$ in 1951 , to $\$ 2,900$ in 1962 . At the same time, beneficiaries who had adult children in their households declined from $34 \%$ in $1941-42$ to $17 \%$ in 1957 , and the proportion of recipients who also received financial assistance from relatives and friends dropped from $11 \%$ to $3 \%$. Private pension plans, in general, affected increasing numbers after 1950. Both public and private plans, though benefits were not widely distributed, were "in place" at war's end (Merriam and Skolnick 1968).

${ }^{31}$ We are struck by the convergence of our argument with Turner's (1976) recent contribution to historical social psychology, partly because we seem to recognize different parts of the same phenomenon coming from radically divergent perspectives. Turner suggests that the last 20 or 30 years has probably seen an increase in our society of individuals who recognize their "real selves" as being anchored not in institutional requirements but in individual impulse. 


\section{Modell, Furstenberg, and Strong}

unattainable "world we have lost," just beyond our memories, of individuals who lacked our current burden of timing marriage correctly, let us recall that such changes are rarely irreversible. ${ }^{32}$ What we have observed, after all, may well be but a fluctuation.

\section{REFERENCES}

Bernard, Jessie. 1940. "The Differential Influence of the Business Cycle on the Number of Marriages in Several Age Groupings." Social Forces 18 (May): 539-49.

Carter, Hugh, and Paul C. Glick. 1970. Marriage and Divorce: A Social and Economic Study. Cambridge, Mass.: Harvard University Press.

Coale, Ansley J. 1971. “Age Patterns at Marriage." Population Studies 25 (July): 193-214.

Davis, Kingsley. 1950. "Statistical Perspective on Marriage and Divorce." Annals, American Academy of Political and Social Sciences 272 (November): 9-21.

Elder, Glen H., Jr. 1974. Children of the Great Depression: Social Change in Life Experience. Chicago: University of Chicago Press.

Elder, Glen H., Jr., and Richard Rockwell. 1975. "Marital Age in Life Patterns." Paper delivered at annual meeting of the American Sociological Association, San Francisco, August.

Furstenberg, Frank F., Jr. 1975. "Review Essay." American Journal of Sociology 81, no. 3 (November): 647-52.

Glick, Paul C. 1946. "Estimates of the Future Number of Families." American Journal of Sociology, 52, no. 3 (November 1946): 235-42.

. 1957. American Families. Census Monographs. New York: Wiley.

. 1974. "Some Recent Changes in American Families." (U.S. Bureau of the Census, Current Population Survey, Special Studies, Ser. P-23, no. 52) Washington, D.C.: Department of Commerce.

Grabill, Wilson J. 1945. "Attrition Life Tables for the Single Population." Journal of the American Statistical Association 40:364-75.

Groves, Earnest R., and William F. Ogburn. 1928. American Marriage and Family Relations. New York: Henry Holt.

Haller, Archibald O., and Alejandro Portes. 1973. "Status Attainment Processes." Sociology of Education 46 (Winter): 51-91.

Hareven, Tamara K. 1976. "Statement of Purpose." Journal of Family History 1:3-5.

Hernes, Gudmund. 1972. "The Process of Entry into First Marriage." American Sociological Review 37 (April): 173-82.

Hill, Reuben. 1970. Family Development in Three Generations. Cambridge: Schenkman.

Jacobson, Paul H., with the collaboration of Pauline F. Jacobson. 1959. American Marriage and Divorce. New York: Rinehart.

Long, Clarence Dickinson. 1960. Wages and Earnings in the United States, 1860-1890. National Bureau of Economic Research. General Series no. 67. Princeton, N.J.: Princeton University Press.

Massachusetts Secretary of the Commonwealth. Various years. Annual Report on the Vital Statistics of Massachusetts.

Merriam, Ida C., and Alfred M. Skolnick. 1968. Social Welfare Expenditure under Public Programs in the U.S. 1929-1966. Social Security Administration, Office of Research Statistics. Research Report no. 25.

Michigan. Various dates. Census and Statistics of the State of Michigan: 1854, 1864, $1874,1884$.

Michigan Secretary of State. Various dates. Annual Report of Births, Marriages, and Deaths in Michigan.

${ }^{32}$ Indeed, Glick (1974), responding to such phenomena as an increase in marriage spread among women, has recently opined that "the familistic style of life" which the war initiated seems to be on the wane again. 
Modell, John. 1975. "Levels of Change over Time." Historical Methods Newsletter 8 (September): 116-27.

Modell, John, Frank F. Furstenberg, Jr., and Theodore Hershberg. 1976. "Social Change in Historical Perspective." Journal of Family History 1 'September): 7-31.

Monahan, Thomas P. 1951. The Age at Marriage in the United States. Philadelphia: Stephenson.

1956. "The Number of Children in American Families and the Sharing of Households." Marriage and Family Living 18 (August): 201-3.

New York Secretary of State. Various dates. Census for the State of New York: 1825, $1835,1845,1855,1865,1875$.

Olson, Keith W. 1974. The G.I. Bill, the Veterans, and the Colleagues. Lexington: University Press of Kentucky.

Panunzio, Constantine. 1943. "War and Marriage." Social Forces 21 (May): 442-45.

Riley, Matilda White, Marilyn Johnson, and Anne Foner, eds. 1972. Aging and Society: A Sociology of Age Stratification. Vol. 3. New York: Russell Sage Foundation.

Robbins, Florence Greehoe. 1944. "Reasons for and against War Marriage." Sociology and Social Research 29 (September-October): 25-33.

Rockwell, Richard C. 1976. "Historical Trends and Variations in Educational Homogamy." Journal of Marriage and the Family 38 (February): 83-90.

Ryder, Norman B. 1965. "The Measurement of Fertility Patterns." Pages 287-306 in Public Health and Population Change, edited by Mindel C. Sheps and Jeanne Clare Ridley. Pittsburgh: University of Pittsburgh Press.

1969. "The Emergence of a Modern Fertility Pattern: United States, 1917-60." In Fertility and Family Planning. A World View, edited by Samuel J. Behrman, Leslie Corsa, Jr., and Donald Freedman. Ann Arbor: University of Michigan Press.

Saveland, Walt, and Paul C. Glick. 1969. "First-Marriage Decrement Tables by Color and Sex for the United States in 1958-60." Demography, vol. 6 (August).

Smith, Daniel Scott. 1973. "The Dating of the American Sexual Revolution: Evidence and Interpretation." In The American Family in Social-Historical Perspective, edited by Michael Gordon. New York: St. Martin's.

Turner, Ralph H. 1976. "The Real Self: From Institution to Impulse." American Journal of Sociology 81, no. 5 (March 1976) 989-1016.

U.S. Bureau of Economic Analysis. 1973. Long Term Economic Growth: 1860-1965. Washington, D.C.: Government Printing Office.

*U.S. Bureau of the Census. 1907. Statistics of Women at Work: 1900.

1913. Thirteenth Census of the United States Taken in the Year 1910. Vol. I. Population, 1910. General Report and Analysis.

- 1922. Fourteenth Census of the United States Taken in the Year 1920. Vol. II. Population 1920: General Report and Analytical Tables.

- 1923. Fourteenth Census of the United States Taken in the Year 1920. Vol. IV. Occupations 1920.

- 1933a. Fifteerth Census of the United States: 1930. Vol. II. Population, General Report: Statistics by Subjects.

1933b. Fifteenth Census of the United States: 1930. Vol. VI. Population, Families.

—_. 1943a. Sixteenth Census of the United States: 1940. Vol. II. Population, Characteristics of the Population.

__ 1943b. Sixteenth Census of the United States: 1940. Vol. IV. Population, Characteristics by Age. Part 1: U.S. Summary. Pts. 2-4: Reports by States.

-1943c. Sixteenth Census of the United States: 1940. Population, Education. Education, Occupation, and Household Relationship of Males 18 to 44 Years Old.

——1943d. Sixteenth Census of the United States: 1940. Population, the Labor Force (Sample Statistics). Employment and Family Characteristics of Women.

—_. 1943e. Sixteenth Census of the United States: 1940. Population, the Labor Force (Sample Statistics). Employment and Personal Characteristics.

* All Bureau of the Census and Census Office publications were published in Washington, D.C., by the Government Printing Office. 
1943f. Sixteenth Census of the United States: 1940. Population, the Labor Force (Sample Statistics). Wage or Salary Income in 1939.

-1943g. Sixteenth Census of the United States: 1940. Population and Housing. Families, General Characteristics.

1946-47. Population Series P-S. Nos. 10, 13, 15, 25.

1947. Sixteenth Census of the United States: 1940. Population, Differential Fertility, 1940 and 1910. Fertility by Duration of Marriage.

. 1948. Current Population Survey. Ser. P-20. No. 23.

1953a. United States Census of Population: 1950. Vol. IV. Special Reports. Pt. 2, chap. D. "Marital Status."

- 1953b. United States Census of Population: 1950. Vol. IV. Special Reports. Pt. 1, chap. A. "Employment and Personal Characteristics."

- 1953c. United States Census of Population: 1950. Vol. II. Characteristics of the Population. Pt. 1. "U.S. Summary."

. 1955a. United States Census of Population: 1950. Special Reports. Pt. 2, chap. A. "General Characteristics of Families."

- 1955b. United States Census of Population: 1950. Vol. IV. Special Reports. Pt. 4, chap. C. "Fertility."

- 1963. United States Census of Population: 1960. Subject Reports 6A. Employment Status and Work Experience.

. 1964a. United States Census of Population: 1960. Subject Reports 4B. Persons by Family Characteristics.

1964b. United States Census of Population: 1960. Subject Reports 4C. Sources and Structure of Family Income.

1964c. United States Census of Population: 1960. Subject Reports 3A. Women by Number of Children Ever Born.

. 1970. Series P-23. Special Studies. No. 32. Probabilities of Marriage, Divorce, and Remarriage.

1972. 1970 Census of Population. Subject Reports 4C. Marital Status.

1973a. 1970 Census of Population. Subject Reports 4B. Persons by Family Characteristics.

1973b. 1970 Census of Population. Subject Reports 4D. Age at First Marriage.

. 1973c. 1970 Census of Population. Subject Reports 4A. Family Composition.

1973d. 1970 Census of Population. Subject Reports 6A. Employment Status and

Work Experience.

. 1973e. 1970 Census of Population. Subject Reports 8A. Sources and Structure of Family Income.

- 1973f. 1970 Census of Population. Subject Reports 3A. Women by Number of Children Ever Born.

- Annually. Current Population Survey. Ser. P-60. Consumer Income.

- Various dates. Current Population Survey. Ser. P-20. Nos. 10, 287.

U.S. Census Office. 1895. Eleventh Census: 1890. Vol. I. Report on Population in the United States. Pt. 1.

1896. Eleventh Census: 1890. Vol. XIII. Report on Farms and Homes: Proprietorship

and Indebtedness in the United States.

. Various dates. Vital Statistics of the United States.

Waring, Joan. 1975. "Social Replenishment and Social Change: The Problem of Disordered

Cohort Flow." American Behavioral Scientist 19 (November/December): 237-56.

Winsborough, Halliman H. 1975. "Statistical Histories of the Life Cycle of Birth Cohorts:

The Transition from School Boy to Adult Male." Working Paper no. 75-19. Center for Demography and Ecology, University of Wisconsin-Madison.

- 1976. "The Transition from School Boy to Adult: Accounting for Change in Process." Working Paper no. 76-13. Center for Demography and Ecology, University of Wisconsin-Madison. 